\title{
Anabasis of Course Reform Practice for Talent Cultivation in Local Music
}

\author{
Yuefang Lv, Zhe Guo
}

XingTai University, Xingtai, 054001, China

\begin{abstract}
Keywords: Local music colleges, Talents of music major, Course reform
\end{abstract}
\begin{abstract}
Local music colleges are a major approach for Chinese local students to learn music knowledge, but some local music colleges gave problems in course setting, which has adverse influence on students majoring in music. Some graduates from music colleges have employment difficulty. The society has high requirements for practical ability of graduates of music major. Colleges reduce students' music class hours so that students have no sufficient time to learn music knowledge and cannot adapt social demands. Some music colleges let students practice in society early, but ignore basic knowledge mastery. Hence, students cannot better learn music knowledge. The rise in public class hours makes the professional music courses reduce again and students' practical course decrease. These problems have a strong impact on students' graduation. Thus, music colleges should pay attention to students' practical ability and enhance course reform.
\end{abstract}

\section{Introduction}

At present, some problems occur to courses of local music colleges, which seriously affects students' employment rate. Thus, music colleges should reform the courses, alter teaching idea, specify course reform approach, optimize course structure, enhance students' practical training, recombine course contents, strengthen ability training penetration, update teaching methods, cultivate students' comprehensive ability, give up traditional teaching evaluation method, comprehensively assess students and improve teachers' professional quality in order to guarantee teaching quality. Only in this way, local music colleges can better reform the courses, enhance students' comprehensive practical ability, make students adapt social demands, boost employment rate and cultivate all-round music talents.

\section{Problems existing in course structure system}

\section{Arrange practice too early}

In recent years, employment competitions for graduates of music colleges have become increasingly fierce. For students, practice is an approach to improve employment competitiveness. Thus, some music colleges arrange practice too early, extend practice time and expand practice space. But, some colleges have employment administration problems which seriously affect students' learning of professional knowledge. Hence, music colleges should measure students' employment practice and learning of professional knowledge. They should not just boost students' employment rate, but also attach importance to mastery of professional knowledge so that students can learn professional knowledge and boost professional quality after employment.

\section{Total teaching hours decrease}

In recent years, the society has higher and higher requirements for students' practical ability, but there are short of teaching resources and teaching equipment in some music colleges. Regardless of professional knowledge teaching or practical ability training, the course time decreases. Since music major has very strong practice nature, most courses aim to cultivate students' professional skills. The decrease in music class hours will affect improvement of practical ability. Thus, students' employment rate will be seriously influenced, and their competitiveness cannot be ensured. Therefore, colleges should lay emphasis on arrangement of music class hours, and make efforts to promote students' competitiveness under the precondition of no reduction of music class hours. 


\section{Increase in public class hours}

Currently, music colleges continuously decrease total class hours. Some local music colleges are difficult to cope with the relationship between professional courses and public courses. The competent department plays an administrative restriction role for public courses. When colleges reform talent training mode, they cannot violate the regulations restricted by the competent department. But, music colleges can autonomously reform professional course. To adapt the situation where public courses cannot be adjusted, music colleges will certainly reduce the class hours of professional courses. Thus, students have no sufficient time to learn professional knowledge and improve practical ability. As a result, they cannot better learn and lose learning motivation and confidence.

\section{Ignore practical teaching}

Students' practical ability is the teaching emphasis of music major which combines theory and practice. Students' practical ability is also valued by the society. But, in some local music colleges, practical teaching is seriously disconnected with theory teaching. When teachers teach theoretical knowledge, they fail to combine practical knowledge and just impart basic theoretical knowledge to students. This cannot better arouse students' learning interest. Students in some local music colleges learn for examinations and just learn theoretical knowledge. They fail to realize the importance of comprehensive practical study and lack subject consciousness. Colleges seldom offer performance chance for students and cannot facilitate students to take active part in social practical teaching. Thus, the students cannot reach the standards required by the society. Thus, the employment rate cannot be improved.

\section{Talent cultivation strategy for music major}

\section{Course structure optimization}

Organization and coordination among each curse can better reflect the value orientation of teaching idea. Music colleges should revise and adjust cultivation scheme. When class hours of professional course are few, course structure should be optimized. The proportion of theoretical courses and practical courses should be rationally allocated, and the credit of practical courses should be controlled. Meanwhile, the time for theoretical courses should be reduced, and the time for practical courses should be increases. Practical training should be enhanced through various activities such as concert, vocal concert and impromptu accompaniment concert. Classroom practical teaching and extracurricular practical training should be combined, and practice, practical study, social practice and concert should also be combined to cultivate students' practical ability and carry out periodical professional skill test for students. Theory teaching, practical teaching, extracurricular practice and performance should be combined to enhance students' practical training so as to make students better learn music knowledge in the activities ${ }^{[1]}$.

\section{Teaching idea change}

Teaching idea can reflect inherent law of teaching and study, the attitude to and concept of teaching activities. Teaching of music major has certain breadth, depth and height. But, some problems exist in the features of music major in local colleges, such as local nature, paying attention to foundation and practice, being unable to improve students' music quality and skills. Therefore, local music colleges should change teaching idea, integrate teaching contents, deepen teaching mode, perfect teaching evaluation, allocate all courses again, make contents of each course disconnected, and better fuse music knowledge and music skills. Students' practical ability can better form and their comprehensive quality can boost only when music colleges change teaching idea and meet the above requirements ${ }^{[2]}$. 


\section{Course content recombination}

Course objective is processed and transformed from course contents. Traditional course content teaching is single, and each course is seriously disconnected. Students' comprehensive practical ability cannot be trained. So, music colleges should recombine course contents, optimize traditional course contents, make course contents more comprehensive, open and fused. For example, harmonic teaching in music major should be dominated by keyboard and harmonic. Impromptu accompaniment content should be penetrated in harmonic teaching, and impromptu accompaniment should be blended in piano teaching so as to make students better learn knowledge of music knowledge, better appreciate music and remove the monotonicity of history knowledge by use of accumulation of music knowledge. Music colleges can better train students' practical ability and achieve crossed and comprehensive ability objective through integrating course contents ${ }^{[3]}$. Only in this way, students' enthusiasm can improve and their learning interest can be aroused.

\section{Teaching method update}

The combination of teaching modes and teaching means applied by teachers is teaching method which can promote teachers and students to jointly complete teaching activities. However, teaching methods of some music colleges are old and cannot highlight students' practice. So, music colleges should realize the importance of practical knowledge study, reduce theoretical knowledge teaching as far as possible and abandon traditional teaching method. Teachers should no longer adopt the teaching mode of teachers' teaching and students' learning. Instead, teachers should give students the opportunity for mutual exchange, enlighten them and apply experience-based teaching method to make them better learn professional knowledge and skills. For instance, during teaching history of music, students may be divided into several groups to analyze and appreciate works and put forward some problems. Team members are required to cooperate for exploration. When teachers teach knowledge, they should not merely tutor the teams, but also give lessons to student individuals. Teams should exchange singing knowledge mutually and interact for accompaniment knowledge. Meanwhile, teachers should pay attention to teaching students in accordance of their aptitude, developing students' potential, communicating with students smoothly and making students learn from others' strong points ${ }^{[4]}$. Students can not just improve professional quality and overall learn professional knowledge, but also arouse learning enthusiasm by applying multimedia teaching tool and changing teaching methods.

\section{Teaching evaluation perfection}

At present, some music colleges are still applying traditional teaching evaluation method to assess students' study. Thus, students learn for examinations and have no awareness to boost their comprehensive quality. Therefore, music colleges should perfect teaching evaluation method and overall assess students. Music teachers should evaluate teaching process and teaching results as per the teaching objectives and make examination modes more diversified, the examination time may be arranged freely. Various forms of assessment may be conducted such as skill training, concert and music report meeting. Both students' learning process evaluation and comprehensive evaluation should be enhanced. Teachers should combine teaching contents and teaching objectives to freely formulate evaluation contents ${ }^{[5]}$ and autonomously decide the proportion of knowledge evaluation and ability evaluation as per core courses of this major. For example, during assessing students' vocal music course, teachers should not just investigate practical singing ability at the end of semester, but also assess students' performance in vocal concert. Students' total performance should be combined. During assessing students' music history, teachers should not merely summarize test scores at the end of semester, but also bring students' ordinary assignments into students' performance evaluation. On in this way, students' enthusiasm can be improved so that students dare not relax in learning process. Such comprehensive and diversified teaching evaluation can effectively boost students' practical ability so that students can learn more comprehensive music knowledge. Teachers should evaluate students in the whole process, highlight the effect of comprehensive investigation and cultivate music talents required by the society. 


\section{Teachers' quality improvement}

Teachers' professional quality will have direct influence on the teaching quality. Professional quality and favorable teachers can effectively improve students' learning efficiency. Teachers are an important channel for colleges to cultivate talents. Especially for music major, teachers are required to own piano performance ability, certain keyboard and harmonic knowledge and even vocal music accompaniment ability. But, teachers of music colleges graduate from pure piano major of music universities, and they cannot master certain history knowledge and music appreciation ability. Hence, music colleges should utilize teaching and researching activities, make teachers to study and discuss teaching contents, regularly invite experts to give lectures in colleges, train teachers periodically, improve teachers' comprehensive quality and teaching quality and make teachers' comprehensive quality reach a higher level.

\section{Rationalization of teaching material selection}

Music talent cultivation objective of some music colleges is solo performer. In terms of teaching material selection, music colleges excessively stress specialty and artistry, pay attention to efficient cultivating mode and fail to realize the importance of students; learning efficiency. Then, textbooks lose practicability. Hence, music colleges should select well teaching materials, update old teaching materials and choose suitable teaching materials. Teaching materials chosen should be diversified. Teaching materials should be selected from multiple channels. Meanwhile, teaching materials should have string artistry, and the students educated should accord with social needs. Besides, it is also required to utilize changes in teaching materials to improve teachers' scientific research level and better promote teachers' teaching ability. Only when textbooks adapt to all students can teachers teach in an all-round way. Meanwhile, students' employment rate can improve, and talents can increase for society.

\section{Absorb talents}

At present, learning atmosphere in some music colleges is not hood enough, which cannot boost students' autonomous learning ability and teachers' teaching efficiency cannot be improved. Music colleges may drive students to learn through recruiting top students and creating good learning atmosphere. These art talents may be placed in each class and give full play to their professional advantages. This may easily generate influence and call on other students to learn. Music talents should be organized together to form a music talent club and hold music performance periodically. This can drive the students with poor foundation and contribute to forming art atmosphere. Colleges' absorption of talents can not just offer superior learning environment for students, but also boost their learning enthusiasm.

\section{Conclusion}

At present, Chinese music colleges still have many problems which seriously influence students' study. So, music colleges should attach importance to their teaching, change teaching idea, update teaching methods and improve teachers' quality and let students receive better and more comprehensive education. Under the precondition of focusing on students' basic knowledge learning, colleges should enhance cultivation of students' practical ability. Only when their practical ability improves can they adapt social needs and promote employment rate.

\section{References}

[1] Qiu Chemgbin, Countermeasure and study on boosting piano teaching quality of music education major in local colleges - case study of Music Department of Guizhou Tongren University. Music Space, 2014(6):92-93,102.

[2] Liu Jie, In training of chorus conducting ability for students of music major in local colleges. Notonly Music, 2012(6):32-33. 
[3] Liu Jie, Exploration of practical teaching reform for music major in local colleges. Journal of Nanchang College of Education, 2012(9):83-84.

[4] Yang Lixia, Practice research of local music in Fujian Province and Taiwan in teaching of local colleges - case study of solfeggio and ear training course. Studies In National Art, 2013,26(2):67-72.

[5] Ai Jiguang, My view on improving piano practice efficiency of students of music major in local colleges. Literature Life (Next Trimonthly Publication), 2013(9):236-237. 